分率八正常ナルモ赤血球沈隆速度八稍 8 㙕加七 v。

局所所昌。兩側鼻前庭八湤皮フ以テ被ハレ。 鼻中隔粘膜八發赤シ。前方キ一ゼルバッハ氏部

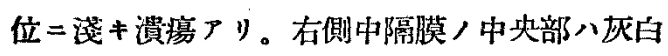

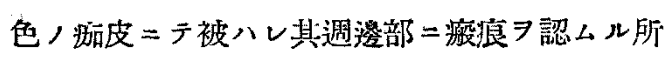
$ア リ$ 。腔ヨ見ル二左側前口蓋弓八發赤シ灰白

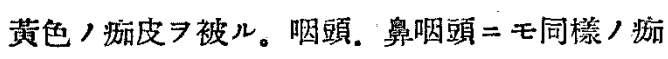
皮アリ。

會厭八秒 大部分前記同樣，知皮二テ被八ル。㕛喉頭後壁 二モ同榡，泇皮存セリ。

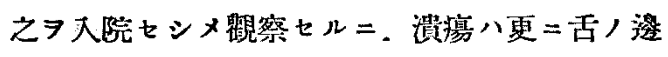

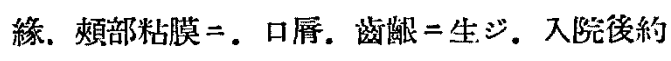
2 ケ年ニシテ初メテ下肢，上肢，耳翼，口嘚部

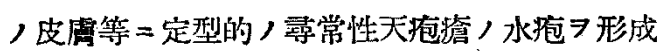
セリ。鼻粘膜. 口腔及ビ咽頭粘膜及ビ皮阔ニテ 八水抱乃至泇皮八生ズルモ間モ温ク消退シ。時

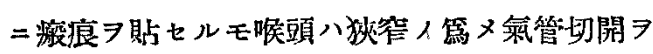
行フノ止ムナキニ至り。眼ハ透二失明セリ。 治療法トシテハ「サルバルサン」其他種々ナル

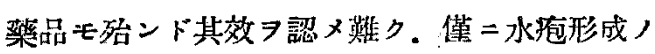
頻度习減少セルノミナリ。

\section{5. 鮕球部神經組織ノ形態學的研究}

伊達基(亭都)

鮕器神經中樞二就テハ. 從來ヨリ諸種, 研究 莱蹟發表七ラレ.閶明トナリシ點卙カラザルモ。 之等, 中特殊神經染色法=ヨリテ检柰セシモ， 八微タタルモノニシテ. 其微細構造二關シテハ

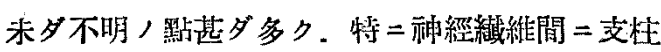
細胞トシテ存在スル膠質細胞／分布㸛態及ビ沐 經㵶維卜，間，關係等二就テハ来ダ㱠ンド其記 载
色法 7 行七。嗅球神經組鐡/形態學的研究 7 企 圆セり。今其研究ノ一項トシテ家兔, 喚球二就 テ實驗シテ、得タル成績 $゙$ 報告セントス。本研究 二八成熟セル健康家鬼 7 用七，其新鮮ナ儿喚球 組織 7 取出シ。(1) Romany Cajal ，錙銀法 ７當教空二於テ改良七シ變法。（2）Horteg'a's Methode /變法。' ( 3 ) Caja1 ，Goldsublinnat 染色法等, 特殊染色法习試 $\bar{~}$. 其前額位及ビ先 狀位二於ヶル切片標本 $フ$ 作製七り。而シテ其構

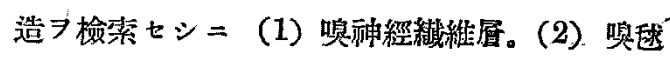



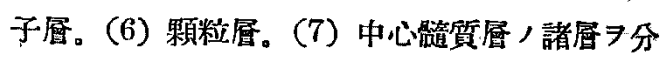
類七り。

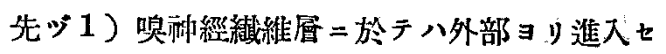

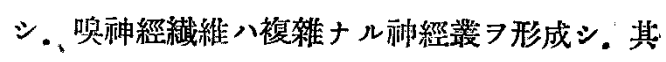

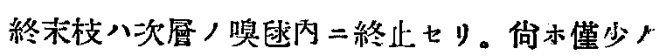

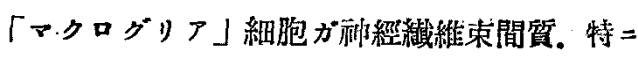
血管周園部二存在スルダ認メタリ。「クログリ ア」細胞ハ殆ンド證明セザリキ。2)嗅越展二 於テ八圆形或八楕圆形 7 呈七ル大小八嗅㡠ガ 1 展乃至數層二並列セリ。而シテ此唤脙へ嗅融經 纎維, 終末枝及ビ第 4 扈，伶帽細胞，樹枝狀突

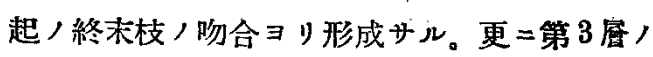
房狀細胞ヨリ生ズル樹枝狀塋起乇亦嗅医内 $=$ 終

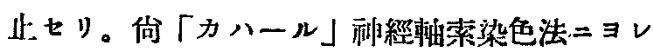
パ. 唤水习圍繞七ル圓形或八多估形，無突把， 小房狀細胞ヨ認ムルモ。該細胞八從來ヨリ或ハ 「グリア」細胞ナりト云ヒ。或ハ神經細胞ナリト 稱へ，其本態，確定7見ザリシモノナルも。ヴ リア」細胞，特殊染色法ナル Goldsublimat 染 色法=ヨレパ. 1 保又ハ $2-3$ 條，比較的長ク シテ，維細ナル突起＼cjkstart認メ、本細胞ハ「グリア」 細胞二屬スルモノナルコトラ確賽ニスルコトタ 
得りリ。而シテ「グリア」細胞ハ主トシテ「マ クログリア丁細胞ニシテ 其間=極メテ短小且 欶小ナル突起ヨ有スル「オりゴデンドログリ 「細胞ヨ含有七ラレキルラ證明セリ。然ルニ 「ミクログリフ」細胞ハ殆ンドえフ認メザリキ。 3) 次=第 3 層，外分子屏=於テ，多數，卵圆 形或八蘶形ノ比較的大ナル房狀細胞が存在シ。

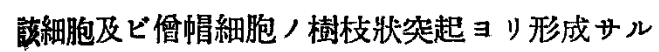
フ認ム。本居二於テハ「マクログリア゙細胞八極 メテ少キモ：細長キ樹枝狀ノ特有ノ突起 7 有ス

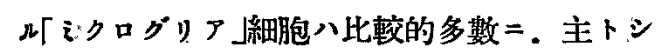
厂房狀細胞又”血管，周園＝存在七り。4)第 4 居ノ僧帽細胞展二於テハ卵圆形又八三危形 7 呈 セル: 大ナル所謂佮帽細胞が一列或八二列 =並 ビ密＝位置七り。其一條，樹枝㹜突起八外分子

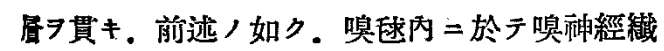
維ノ終末枝卜特有, 瀻維網 7 形成七り。文或分 枝八單二外分子屏＝於テ終止スルカ．又八他， 神祣節細胞ノ分枝ト互二吻合セルラ認メタリ。 更二一條ノ軸菜突起八顆粒屏＝入リ咱菜ノ神經

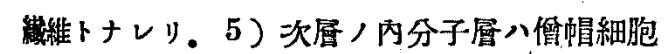
及ビ房狀細胞ノ軸索突起ヨリ分レシ側枝ヨリ成


一部モ之=關與セリ。6）更=內層，顆粒虽=

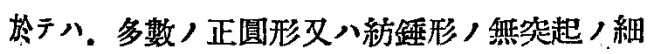
胞. 郎于所謂顆粒細胞力聚落溙二存在シ。其間

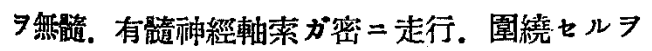

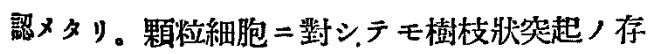
在ヨ稱つル人モフルモ. 余ノ檢索七シ處ニテハ 本細胞へ無突起性 神經篩細胞 ナル リ. 次こ「マクログリア」細胞八㽢帽細胞展 り內展 $=$ 向フニ從七渐次其數 7 增加シ。内分子

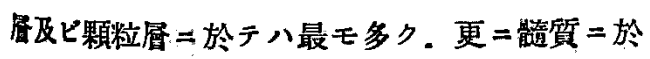

テモ之ア認メタリ。之ニ反シ「ミクログリア」” 細胞八唯散在性：=愎朋セシ＝過ギズ．7）中心

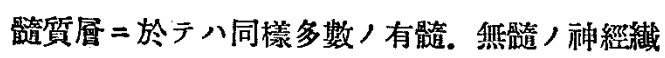
維屋 認メ。而シテ㖟球室二接スル面ニ於テハ 「エペンヂウム」細胞ニ依リテ被ハレテキル 䚋察七り。

\section{6 旗郖惡性腫富二對スル外頸動脈} 結禁ノ治療的價値二就テ

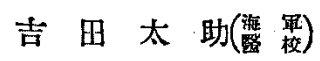

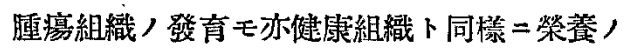
補給ト不可分，關係二在ル事八㗪々スル迄モ热 イガ. 殊=發育力旺盛十惡性腫劰 =於テ 八其關 係ハ一屡密接ナルペク，從テ腫瘍局所:分布

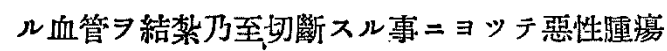
ノ發育 7 遲延乃至八抑制シ得ルニ非ズヤトノ考 ヘ八誰シモ想到スル所デ，我國二在テモ藤繩。

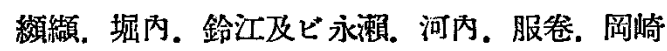

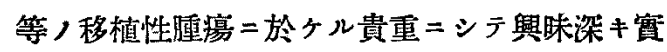
驗的研究力墢表七ラレテ居ル。茲二是等，研究 成績ヨ要約スレバ.

第 1. 腫瘍局所，動脈 $\ni$ 結禁乃至切斷 スル ヤ. 一定期間腫演ノ發育八障碍七ラル、ガ。併 シ之 7 完全二阻止スル事八不可能デ有ル。

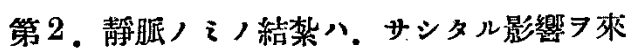
タサナイガ. 動脈卜同時ニ之ヨ結桨スレバ其效 果八動脈ノ $\mathrm{i}$ ，場合ヨリモ稍に著明デ有ル。

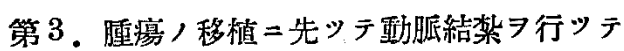
㽡り場合ヨリモ。移植隀瘍，發有旺盛期二到》 テ結禁スル方が效果的デ有ルト云つ事ニナツテ 几。

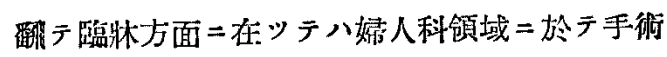
，適應期 7 失シタ子宮癌腫二對シ下腹腔動脈 7 結装スル事ガ.カナリ古っョリ行ハレテ.止血並 